\title{
Factors Related to Depression Level among Malaysian Students Batch 2015-2018 in Universitas Sumatera Utara
}

\author{
Jesvinder Amaiappan'), Putri Chairani Eyanoer²) \\ 1)Faculty of Medicine, Universitas Sumatera Utara, Medan, Indonesia \\ 2)Department of Community and Preventive Medicine, Faculty of Medicine, \\ Universitas Sumatera Utara, Medan, Indonesia
}

\section{ABSTRACT}

Background: Depression is the most common psychological disorder encountered and is a disorder that is mainly characterized by sad and depressed emotional conditions and is associated with cognitive, physical, and interpersonal symptoms. Depression has several things such as loss of energy, changes in appetite, lack of sleep, restlessness, decreased concentration, doubt, anxiety, feelings of worthlessness, guilt or despair, and thoughts of self-harm or suicidal ideation. This study aimed to investigate the factors related to depression in Malaysian students in Universitas Sumatera Utara.

Subjects and Method: This was a crosssectional study conducted at the Universitas Sumatera Utara, Indonesia, from September to October 2019. A total of $1002^{\text {nd }}$ and $3^{\text {rd }}$ semester Malaysian students from Faculty of Medicine, Faculty of Dentistry, and Faculty of Pharmacy, in Universitas Sumatera Utara, who live in Medan were selected by consecutive sampling. The dependent variable was depression. The independent variables were social adaptation, academic achievement, loneliness/ homesickness, culture shock, and study pressure. Depression level was measured by the Korean version of the Center for Epidemiologic Studies Depression Scale (CES-D) questionnaire that was validated using the Mini International Neuropsychiatric Interview (MINI).

Results: From 100 students, the average age of 22 years $(\mathrm{Mean}=22 ; \mathrm{SD}=1.58)$. Social adaptation, academic achievement, loneliness, culture shock, and study pressure were positively associated with depression in Malaysian students batch 2015-2018, Universitas Sumatera Utara.

Conclusion: Social adaptation, academic achievement, loneliness, culture shock, and study pressure are positively associated with depression in Malaysian students.

Keywords: depression, social adaptation, culture shock, Malaysian students

\section{Correspondence:}

Putri Chairani Eyanoer. Department of Community and Preventive Medicine, Faculty of Medicine, Universitas Sumatera Utara, Medan, Indonesia. Email:putrieyanoer@usu.ac.id. Mobile: +62-813 7023-2513.

\section{Cite this as:}

Amaiappan J, Eyanoer PC (2020). Factors Related to Depression Level among Malaysian Students Batch 2015-2018 in Universitas Sumatera Utara. J Epidemiol Public Healt. 05(02): 207-217. https://doi.org/10.26911/jepublichealth.2020.05.02.08.

\section{(i) (ㅇ) Journal of Epidemiology and Public Healthis licensed under a Creative Commons}

c. Attribution-NonCommercial-ShareAlike 4.0 International License.

\section{BACKGROUND}

Depressive disorders are characterized by sadness, loss of interest or pleasure, feelings of guilt or low self-esteem, sleep or appetite disturbances, feelings of fatigue, and decreased concentration (WHO, 2017).
Depression is a medical disease with many symptoms, including physical ones. Sadness is only a small part of depression. Some people with depression may not feel sadness at all, but become more irritable, or simply lose interest in things they normally like (NIMH, 2010). Depression can be long 
or recurring, substantially disrupting an individual's ability to function at work or school or dealing with it every day of life, that depression can cause suicide (WHO, 2017).

Depression is a type of mental disorder that is often found, with a lifetime prevalence of around $15 \%$, with the possibility of reaching $25 \%$ in women (Ballo et al., 2012). The total number of people living with depression in the world is 322 million (WHO, 2017). The prevalence of mental emotional disorders of adolescents aged 15 years and above in Indonesia such as depression is $6.1 \%$ of the general population while in North Sumatra the prevalence reaches 7.5\% (RISKESDAS, 2018). The World Mental Health Survey conducted in 17 countries shows that on average about 1 in 20 people are reported to have experienced depression before. Depression is expected to continue to increase by $5.70 \%$ by 2020 (Genatha, 2018).

The American College Health Association-National College Health Assessment (ACHA-NCHA) conducted a study of students and found that $\pm 30 \%$ of students experienced depression (NIMH, 2010). In addition to the above research, another study involving 1,455 students also reported that depressive symptoms appeared as they entered the beginning of the lecture year, the 4 main causes were academic, economic, solitude, and difficulties in socializing (Susan et al., 2001). Studies in various countries shows that the incidence of depression in medical students is higher when compared to the general population. Givens and Tjia at the University of California, San Francisco found that 1 out of 4 medical students experiencing depression (Hadianto et al., 2014).

Among the first factors contributing to the level of depression is social adaptation. Attending university for the first time might prove to be an important test of one's adjustment. Besides being unfamiliar with university life, new students may doubt whether they will be able to meet the expectations of parents and friends in addition to the expectations they have for themselves (Dyson et al., 2006). To adapt to the surrounding environment, an individual must overcome and manage problems, challenges, and demands in his daily life. Individuals rely on changes in behavior and coping strategies when adapting to their environment (Dyson et al., 2006). Berry (1985) identified four adaptation problem domains in studying acculturation of foreign students; environment (such as climate, clothing, housing and food), sociocultural (such as interpersonal and intergroup relations, and social contact in general), academic (such as courses, examinations, deadlines and language understanding) and psychological (such as mental health status, price self and identity (Yu, 2010).

The next factor is academic achievement. Academic productivity is measured using the average student's undergraduate grade point (GPA), a fairly objective measurement of students "about work performance" provided by outside evaluators based on performance tests and students ('workers') reporting absenteeism and self-reported presenteeism (Hysenbegasi et al., 2005). Among medical students, depression has been reported to be caused by academic demands, examinations, inability to cope, helplessness, increased psychological pressure, mental strain and too much workload (Jadoon et al., 2010). This reflects a reduction in learning opportunities, a decrease in the level of information absorbed and / or a decrease in their ability to represent their learning (Hysenbegasi, et al., 2005).

In addition to the academic achievement factor, there is also a loneliness/ 
homesickness factor. Loneliness is associated with personality disorders and psychosis, decreased cognitive performance, increases the likelihood of Alzheimer's disease, eliminates executive control, and improves depressive symptoms (Halim, et al., 2016). Other risk factors for intense yearning that are common to domestic and international students include young chronological age, little prior experience away from home, low control, perceived distance away from home, high dependence on family members, insecure bonds with parents or caregivers who do not support and perception of discrimination. Dependent personality and strong attachment are also related to longing for students. Finally, students who are socially anxious and therefore have difficulty making friends and have the risk of becoming dissatisfied with school and developing intense yearning (Thurber, et al., 2012).

In addition, there are also factors such as culture shock. The term culture shock was first introduced by an anthropologist named Oberg. According to him, culture shock is defined as excessive anxiety that arises from the loss of all symbols and symbols that are familiar in social relations (Suryandari, 2012). Culture shock can cause depression and tension when an individual is faced with a situation that has never been felt before, such as differences in language, dress style, food and eating habits, interpersonal relationships, weather (climate), time of study, eating and sleeping, male and women behavior, regulations, political systems, economic development, education and teaching systems,hygiene, financial arrangements and public transportation (Siregar et al., 2018).

Difficulty in concentration, difficulty in remembering, not being able to study well, not concentrating, unable to understand language, certain subjects are very difficult, not interested in subjects are among the causes of study pressure (Kumaraswamy, 2013). As written in the $\mathrm{CNN}$ Indonesia article (2016), that one third of medical students in the world experience depression (Martasari et al., 2018). The Faculty of Medicine applies a new curriculum known as the Competency Based Curriculum (CBC), covering several activities, namely small group discussions (SGD), expert lectures, practicums, skills labs, panel experts, and local content of this learning system also demanding students become more active. From Nur's study results (2015), at Padjajaran University (UNPAD) shows that around 6o percent of students feel they have not been able to adjust to academic demands properly. This is because of their difficulties in completing academic assignments, difficulties in going through relationships with new friends, are not familiar with the lecture system and are still very dependent on parents (Maulina, et al., 2018).Our study aimed is to investigate the factors that are related to the level of depression in Malaysian students batch 2015-2018 in Universitas Sumatera Utara.

\section{SUBJECTS AND METHOD}

\section{Study Design}

This was a cross-sectional study conducted at the Universitas Sumatera Utara, from September to October 2019.

\section{Population and Sample}

The study population was all semester II VIII Malaysian students of Faculty of Medicine, Faculty of Dentistry, and Faculty of Pharmacy, Universitas Sumatera Utara, who live in Medan. A total 100 participants were obtained with consecutive sampling.

\section{Study Variables}

The dependent variable was depression. The independent variables were social adaptation, academic achievement, loneli- 
ness/ homesickness, culture shock, and study pressure.

\section{Operational Definition of Variables} Depression level. Depression is a common mental disorder, characterized by ongoing sadness and a loss of interest in activities that you normally enjoy, accompanied by an inability to carry out daily activities, for at least two weeks.

Social adaptation. Is the ability of a group of people or an individual to learn and change to adapt.

Academic achievement. Is an achievement level of success about a goal, because a learning effort has been carried out by someone optimally.

Loneliness/ homesickness. It is the feeling of loss and dissatisfaction that results from a mismatch between the type of social relationship we want and the type of social relationship we have.

Culture shock. Is a profound and negative response to depression, frustration, and disorientation experienced by people who live in a new cultural environment.

Study pressure. Is the stress caused by compact learning.

\section{Research Instruments}

Depression was measured by the Korean version of the Center for Epidemiologic Studies Depression Scale (CES-D) questionnaire that was validated using the Mini

Table 1. Sample Characteristics

\begin{tabular}{lcc}
\hline Sample Characteristics & Total (n) & Percentage (\%) \\
\hline Gender & 21 & 21 \\
$-\quad$ Male & 79 & 79 \\
- Female & & \\
Faculty & 44 & 44 \\
$-\quad$ Faculty of Medicine & 39 & 39 \\
$-\quad$ Faculty of Dentistry & 17 & 17 \\
- Faculty of Pharmacy & & \\
Batch & 20 & 20 \\
$-\quad 2015$ & 33 & 33 \\
$-\quad 2016$ & 16 & 16 \\
$-\quad 2017$ & 31 & 31 \\
\hline
\end{tabular}

International Neuropsychiatric Interview (MINI). The questionnaire used to measure the independent variables on students was taken from a study entitled "stress levels and influencing factors for Malaysian students in 2013, 2014 and 2015 at the University of North Sumatra" by Nik Ahmad Asyraf Bin Nik Ab Halim and added several questions and validated.

\section{Data analysis}

All data collected is processed using a statistical software in accordance with the purpose of the study. Data were analyzed descriptively (univariate) to find out the sample characteristics. Then proceed with the Chi-square to examine the relationship between the independent and dependent variables.

\section{Research Ethics}

Research ethics includes informed consent, anonymity, confidentiality, and permit ethics. The ethical eligibility in this study comes from the Medical Research Ethics Commission of the Medical Faculty, Universitas Sumatera Utara/ H. Adam Malik Hospital, Medan with number: 42/TGL/KEPK/FK USU-RSUP HAM/2019.

\section{RESULTS}

1. Sample characteristics

From all students the average age was 22 years $(\mathrm{Mean}=22 ; \mathrm{SD}=1.58$. 
Amaiappan et al./ Factors Related to Depression Level among Malaysian Students

Most of the sample was female (79\%), Faculty of Pharmacy (17\%). One third studies at the Faculty of Medicine (44\%). students came from the batch 2016 (33\%).

The lower number of students came from

Table 2. Frequency Distribution Based on Levels of Depression

\begin{tabular}{cccc}
\hline Depression Level & Total (n) & Percentage (\%) \\
\hline - & Severe Depression & 64 & 64 \\
- Moderate Depression & 22 & 22 \\
- & Mild Depression & 10 & 10 \\
- No Depression & 4 & 4 \\
\hline
\end{tabular}

The respondents' levels of depression can be seen in table 2. In the study, 64 people suffered from severe depression (64\%), 22 people with moderate depression
(22\%), 10 people with mild depression (10\%) and only 4 people who did not experience depression (4\%).

Table 3. Relationship between Independent Variables and Levels of Depression

\begin{tabular}{|c|c|c|c|c|c|c|c|c|c|}
\hline \multirow{2}{*}{$\begin{array}{l}\text { Independent } \\
\text { Variables }\end{array}$} & \multicolumn{2}{|c|}{$\begin{array}{c}\text { Severe } \\
\text { Depression }\end{array}$} & \multicolumn{2}{|c|}{$\begin{array}{c}\text { Moderate } \\
\text { Depression }\end{array}$} & \multicolumn{2}{|c|}{$\begin{array}{c}\text { Mild } \\
\text { Depression }\end{array}$} & \multicolumn{2}{|c|}{$\begin{array}{c}\text { No } \\
\text { Depression } \\
\end{array}$} & \multirow[t]{2}{*}{$\mathbf{p}$} \\
\hline & $\mathbf{n}$ & $\%$ & $\mathbf{n}$ & $\%$ & $\mathbf{n}$ & $\%$ & $\mathbf{n}$ & $\%$ & \\
\hline Social Adaptation & 45 & 70.3 & 12 & 54.5 & 0 & 0.0 & $\mathrm{O}$ & 0.0 & \multirow{2}{*}{$<0.001$} \\
\hline $\begin{array}{l}\text { Unable to adapt } \\
\text { Able to adapt }\end{array}$ & 19 & 29.7 & 10 & $45 \cdot 5$ & 10 & 100 & 4 & 100 & \\
\hline \multicolumn{10}{|l|}{ Academic } \\
\hline Achievement & 28 & 43.8 & 2 & 9.1 & 1 & 10.0 & $\mathrm{O}$ & 0.0 & \multirow[b]{2}{*}{0.003} \\
\hline $\begin{array}{l}\text { Unable to achieve } \\
\text { Able to achieve }\end{array}$ & 36 & 56.3 & 20 & 90.9 & 9 & 90.0 & 4 & 100 & \\
\hline \multicolumn{10}{|l|}{$\begin{array}{l}\text { Loneliness/ } \\
\text { Homesickness }\end{array}$} \\
\hline Unable to handle & 48 & 75.0 & 12 & 54.5 & 1 & 10.0 & 1 & 25.0 & \multirow[t]{3}{*}{$<0.001$} \\
\hline separation & 16 & 25.0 & 10 & $45 \cdot 5$ & 9 & 90.0 & 3 & 75.0 & \\
\hline $\begin{array}{l}\text { Able to handle } \\
\text { separation }\end{array}$ & & & & & & & & & \\
\hline \multicolumn{10}{|l|}{ Culture Shock } \\
\hline Unable to accept & 38 & 59.4 & 8 & 36.4 & 1 & 10.0 & o & 4 & \multirow[t]{2}{*}{0.003} \\
\hline Able to accept & 26 & 40.6 & 14 & 63.6 & 9 & 90.0 & $\mathrm{O}$ & 100 & \\
\hline \multicolumn{10}{|l|}{ Study Pressure } \\
\hline Compact & 50 & 78.1 & 16 & 72.7 & 4 & 40.0 & 1 & 25.0 & \multirow[t]{2}{*}{0.016} \\
\hline Not Compact & 14 & 21.9 & 6 & 27.3 & 6 & 60.0 & 3 & 75.0 & \\
\hline
\end{tabular}

Table 3 shows the results of the relationship between social adaptation and the levels of depression. Students who were severely depressed were $70.3 \%$, students who suffered moderate depression were $54.5 \%$, while students with mild depression were $0.0 \%$ and respondents who were not depressed were found $0.0 \%$. Those were the respondents that were unable to adapt social adaptation. From the results of the statistical analysis, there is a significant relationship between social adaptation and the level of depression in Malaysian students at Universitas Sumatera Utara.

Then, the table shows the results of the relationship between academic achievement and the levels of depression. It was found that the respondents who were severely depressed and who were unable to achieve were $43.8 \%$. Students who went through moderate depression were 9.1\% and those who were mildly depressed were 
10.0\%. From the results of statistical analysis, there was a significant relationship between academic achievement and the level of depression in Malaysian students at Universitas Sumatera Utara.

After on, the table shows the results of the relationship between loneliness/ homesickness with the levels of depression. The respondents who were severely depressed were $75.0 \%$, students with moderate depression were $54.5 \%$ while the students with mild depression, were only $10.0 \%$ and respondents who were not depressed were 25.5\%. Those were the students that were unable to handle separation from family. From the results of statistical analysis, there is a significant relationship between loneliness/ homesickness and the level of depression in Malaysian students at Universitas Sumatera Utara.

Then, the table shows the results of the relationship between culture shock and the levels of depression. The students with severe depression were $59.4 \%$, respondents who suffered moderate depression were $36.4 \%$ while respondents with mild depression were $10.0 \%$ and respondents who were not depressed were $0 \%$. Those were the respondents who were unable to accept culture shock. From the results of statistical analysis, there is a significant relationship between culture shock and the level of depression among Malaysian students at Universitas Sumatera Utara.

Finally, the table shows the results of the relationship between study pressure and the levels of depression. Respondents who were severely depressed were $78.1 \%$, students who suffered moderate depression were $72.7 \%$ while the respondents with mild depression were $40.0 \%$ and students who were not depressed were $25.0 \%$. Those were the students who felt that study pressure was compact. From the results of statistical analysis, there is a significant relationship between study pressure and depression rates in Malaysian students at Universitas Sumatera Utara.

\section{DISCUSSION Characteristics}

In this study, the average age of a student is 22 years old and the standard deviation is 1.578. The number of male students is 21 people (21\%) and the number of female students is 79 people (79\%). The number of students from the Faculty of Medicine were 44 people (44\%), students from the Faculty of Dentistry were 39 people (39\%) and students from the Faculty of Pharmacy were 17 people (17\%). The number of students from the batch of 2015 were 20 people (20\%), students from the batch of 2016were 33 people (33\%), students from the batch of 2017 were 16 people (16\%) and students from the batch of 2018 were 31 people (31\%).

The results of this study are consistent with the results of the research of Goebert et al. (2009) which stated that the study was conducted on 1723 students in which, 808 people $(46.90 \%)$ were male and 915 people $(53.11 \%)$ were female who were experiencing depression.

\section{Frequency distribution of depression}

In this study, the number of students with severe depression were 64 (64\%), the number of students with moderate depression were 22 (22\%), the number of students with mild depression were 10 people (10\%) and the number of students who did not experience depression were 4 people (4\%).

Similar results were obtained from studies of Hawaii, Iowa, Cincinnati, North California, Southwest Texas, and Washington in foreign students showing that there was a significant relationship in Depressive 
Symptoms in Medical Students and Residents: A Multi school Study. Severe or mild depression occurs because of differences in sleep duration, with less sleep being reported by respondents experiencing affective disorders resulting in insufficient quality and quantity of sleep, resulting in decreased student academic performance. A few African American students also feel the loneliness since they have been separated from their families due to studying abroad and are unable to adapt socially which can cause severe depression (Goebert et al., 2009).

\section{Relationship between Social Adap- tation and Depression Level}

In this study, it was found that 45 students (70.3\%) who were severely depressed were unable to adapt, and only 19 students (29.7\%) who were severely depressed were able to adapt to social adaptation. Students who are moderately depressed, 12 people (54.5\%) were unable to adapt and as many as 10 people ( $45.5 \%)$ were able to adapt to social adaptation. For students who were mildly depressed, no one (o\%) was unable to adapt and 10 people (100\%) were able to adapt to social adaptation. For students who were not depressed, there was also no people (o\%) who were unable to adapt and 4 people $(100 \%)$ who were able to adapt to social adaptation.

The same results were also obtained from a study in Yogyakarta on migrant students showing that there was a significant relationship between coping mechanisms and the level of depression in immigrant college students at the Alma Ata Higher Education Study Program. His research concluded that the majority of the students who were detected were unable to adapt and had mild depression (Krisdianto et al., 2015).

To adjust life on campus and attend university for the first time can be a stress- ful experience for students. Because of the challenges faced when adapting to these life changes, students risk experiencing more specific mental health problems such as excessive depression and suicidal thoughts (Sharma et al., 2015).

This problem can be overcome with coping strategies that focuses on problems and coping strategies that focuses on emotions. This type of coping strategies has been associated with different adaptation outcomes, with coping that focuses on problems that are associated with decreased levels of depression and coping that focuses on emotions related to malfunctioning functions and pressures (Dyson et al., 2006).

\section{Relationship between academic} achievement and depression level

In this study, it was found that 28 students (43.8\%) who were severely depressed were unable to achieve, and only 36 people (56.3\%) who were severely depressed were able to achieve academically. Students who were moderately depressed, 2 people (9.1\%) were unable to achieve and as many as 20 people (90.9\%) were able to achieve academically. For students who were mildly depressed, 1 person (10\%) was unable to excel and 9 (90\%) were able to achieve academically. For students who were not depressed, no one (o\%) was unable to achieve and 4 people (100\%) were able to achieve academically.

The same results obtained from a research in Pontianak on medical education program students at the Faculty of Medicine, Tanjungpura University showed that there was a significant relationship between the second year of study and the level of depressive symptoms and became more significant from year to year in the field of academic achievement. According to the results of his study, the prevalence of students who had symptoms of depression 
was more common in the second year (39.4\%), and followed in the first year (32.9\%). The high prevalence of depressive symptoms in the first year is due to changes in the new learning environment and a busy schedule. In the second year, the learning material and clinical skills that must be learned got heavier so the depressive symptoms increased and reached a peak. (Hadianto et al., 2014).

This depression can push students to negative end including completing medical bachelor degree, impaired ability to work efficiently, setback in relationships, fatigue, increased suicidal ideation and additional problems in providing health services (Jadoon et al., 2010).

Greater attention to psychological well-being is needed by medical students. The Student Guidance Program has been established by most medical faculties including Universiti Putra Malaysia, which offers consultations to students who may need assistance from academic staff (Sherina, 2003).

\section{Relationship between loneliness/} homesickness and depression level

In this study, the results showed that students who were severely depressed were unable to handle separation as many as 48 people $(75 \%)$, and only 16 people (25\%) who were severely depressed were able to handle separation with loneliness/ homesickness. Students who were moderately depressed, 12 people (54.5\%) were unable to handle separation and as many as 10 people $(45.5 \%)$ were able to handle separation with loneliness/ homesickness. For students who were mildly depressed, 1 person (10\%) was unable to handle separation and 9 people (90\%) were able to handle separation from loneliness/ homesickness. For students who were not depressed, only 1 person (25.0\%) was unable to handle separation and 3 people
(75\%) were able to handle separation from loneliness / homesickness.

Similar results were obtained from studies at a college in Kenya showing that there was a significant positive relationship between loneliness and depression in college students. According to his research, the views of individuals who were frightened and busy, had negative feelings where they may find it difficult to adjust and had lack communication skills due to social avoidance. Unsafe feelings or misgivings felt by students can lead to a bad relationship between students and their friends and the community will distance themselves from them, where things like this contribute to loneliness (Daniel, 2013).

From the results of the study of Roh et al. (2010) and Do (2008), the same results was obtained by finding a significant relationship between loneliness with the level of depressive symptoms. Students who were depressed often stayed alone in dormitories or rented houses. Living with parents or family is a protective factor for students to experience symptoms of depression. This is because when students stay at home together with parents or family, students can live comfortably and quietly and can share their problems with the family

Causes of loneliness are deficiencies in relationships, desired changes in relationships, causal attributions and interpersonal behaviour (Halim, et al., 2016).

Providing a fun and relaxed orientation where new students have the opportunity to connect socially and familiarize themselves with the university before class begins. In addition, getting used to the feeling of losing home, so students are convinced that everyone is missing something about the house. Students also need to hold their intense desires as a positive reflection of the attachment they have to people, 
places, and things at home (Thurber, et al., 2012).

\section{Relationship between Culture Shock and Depression Level}

In this study, the results showed that students who were severely depressed could not accept as many as 38 people $(59.4 \%)$, and only 26 people (40.6\%) who were severely depressed were able to accept culture shock. Students who were moderately depressed, 8 people $(36.4 \%)$ were unable to accept and as many as 14 people (63.6\%) were able to accept culture shock. For students who were mildly depressed, 1 person (10\%) was unable to accept and 9 people (90\%) were able to accept culture shock. For students who were not depressed, no one (o\%) was unable to accept and 4 people (100\%) were able to accept culture shock.

Similar results were obtained from studies in Australia on foreign students showing that there was a significant relationship found between culture shock and the three DASS scales and showed that the stronger the experience of students about culture shock, the higher the level of depression. Culture shock is a very clear challenge for the welfare of international students, especially in countries of origin that are far different culturally. These international students have feelings of discomfort, dislocation and distress, but do not continue to an extreme degree. Difficulties and longings experienced by students through far-flung families, friends and familiar things that are expected at home when in another country (Thomson, et al. 2006).

Every student naturally experiences culture shock as a result of his/her transfer from the old high school environment to the new university environment. Habits in a new environment can cause pressure and result in the academic competence of these students (Suryandari, 2012).

An attitude of respecting and accepting all the diversity or heterogeneity of existing cultures will make it easier for businesses to adapt to new cultures (Devinta et al., 2015)

\section{Relationship between Study Pressure and Depression Level}

In this study, the results showed that students who were severely depressed due to the compact of study pressure were 50 people (78.1\%) and only 14 people (21.9\%) were severely depressed due to the study pressure that were not compact. Students who were moderately depressed, 16 people (72.7\%) due to study pressure were compact and as many as 6 people (27.3\%) due to study pressure that was not compact. For students who were mildly depressed, 4 people (40\%) were due to compact study pressure and 6 people $(60 \%)$ due to noncompact study pressure. For students who were not depressed, only 1 person (25\%) due to study pressure was compact and 3 people $(75 \%)$ due to study pressure that was not compact.

The same results were also obtained from a study in Medan in the 2014 Faculty of Medicine students of the North Sumatra University of Muhammadiyah showing that there was a relationship between thesis writing and depression, using a simple linear regression test. This shows that there was a significant influence between thesis writing and depression. According to his study, this was influenced by the demand to be more active in the learning process, especially the co-assistent level which has a heavier responsibility burden compared to the pre-clinical level, a more competitive atmosphere of co-assistent learning, a compact schedule, wider teaching materials and applicative (Nst et al., 2018). 
Students have not been able to adjust to academic demands well, due to their difficulties in completing academic assignments, difficulties undergoing relationships with new friends, not familiar with the lecture system and are still very dependent on parents (Maulina et al., 2018).

\section{AUTHOR CONTRIBUTION}

Jesvinder Amaiappan carried out the investigation and analysed data. Putri Chairani Eyanoer supervised the study.

\section{CONFLICT OF INTEREST}

The authors declare that the study was conducted in the absence of any comercial or financial relationships that could be construed as a potential conflict of interest.

\section{FUNDING AND SPONSORSHIP}

None.

\section{ACKNOWLEDGEMENT}

The authors gratefully acknowledge that the present research is supported by Ministry of Research and Technology and the Higher Education Republic of Indonesia, Research and Community Service, Universitas Sumatera Utara.

\section{REFERENCE}

Ballo IR, Kaunang TMD, Munayang H, Elim C (2012). Profil lanjut usia dengan depresi yang tinggal di balai penyantunan lanjut usia senja cerah Manado. Jurnal Biomedik. 4(1): 5967. https://doi.org/10.35790/jbm.4.1.2012 .753 .

Daniel K (2013). Loneliness and depression among university students in Kenya. Global Journal of Human Social Science. 13(4). https://globaljournals.org/GJHSS_Volume13/2-Lonelinessand-Depression-among-University.pdf.
Do QD, Tasanapradit P (2008). Depression among the first year medical students in University of Medicine And Pharmacy, Hochiminh City, Vietnam. J Health Res. 22: 1-4. Retrieved from https://heo1.tci-thaijo.org/index.php/jhealthres/article/view/156073.

Dyson R, Renk K (2006). Freshmen adaptation to university life: depressive symptoms, stress, and coping. J Clin Psychol. 62(10): 1231-44. https://doi.org/10.1002/jclp.20295

Genatha DW (2018). Hubungan antara depresi dengan kejadian hipertensi pada ibu hamil. Jurnal Berkala Epidemiologi. 6: 211. http://dx.doi.org/10.20473/jbe.V6I32018.209-218.

Goebert D, Thompson D, Takeshita J, Beach C, Bryson P, Ephgrave K, Kent A, Kunkel M, Schechter J, Tate J (2009). Depressive symptoms in medical students and residents: A multi school study. Acad Med. 84(2): 23641. https://doi.org/10.1097/acm.obo13e31819391bb.

Hadianto H (2014). Prevalensi dan faktorfaktor risiko yang berhubungan dengan tingkat gejala depresi pada mahasiswa program studi pendidikan dokter fakultas kedokteran Universitas Tanjungpura. Jurnal Mahasiswa PSPD FK Universitas Tanjungpura. 1(1). Retrieved from https://jurnal.untan.ac.id/index.php/jfk/article/vie $\mathrm{w} / 7827 / 7924$.

Halim CF, Dariyo A (2016). Hubungan psychological well-being dengan loneliness pada mahasiswa yang merantau. Jurnal Psikogenesis. 4: 172-173. https://doi.org/10.24854/jps.v4i2.344.

Hysenbegasi A, Hass SL, Rowland CR (2005). The impact of depression on the academic productivity of university students. J Ment Health Policy Econ. 8(3): 145-51. PMID: 16278502. 
Jadoon NA, Yaqoob R, Raza A, Shehzad MA, Choudhry ZS (2010). Anxiety and depression among medical students: A cross-sectional study. J Pakistan Med Assoc. 6o(8):699-702. PMID: 20726214.

Kumaraswamy N (2013). Academic stress, anxiety and depression among college students- a brief review. International Review of Social Sciences and Humanities. 5(1): 135-143.

Krisdianto MA, Mulyanti (2015). Mekanisme koping berhubungan dengan tingkat depresi pada mahasiswa tingkat akhir. Jurnal Ners dan Kebidanan Indonesia. 3(2): 71-76. http://dx.doi.org/10.21927/jnki.2015.3(2).71-76.

Martasari OD, Ediati A (2018). Harapan orang tua dan depresi pada mahasiswa program studi S1 kedokteran umum. Jurnal Empati. 7(3): 835-842.

NIMH (2010). Depression and College Students. National Institute of Mental Health.

RISKESDAS (2018). Prevalensi depresi pada penduduk umur $\geq 15$ tahun menurut provinsi, 2018. Retrieved from https://kesmas.kemkes.go.id/assets/ upload/dir_519d41d8cd98foo/files/ Hasil-riskesdas-2018_1274.pdf

Roh MS, Jeon HJ, Kim H, Han SK, Hahm BJ (2010). The prevalence and impact of depression among medical students: A nationwide among medical students. Acad Med. 85(8): 1384-90. https://doi.org/10.1097/acm.obo13e3 $181 \mathrm{df} 5 \mathrm{e} 43$.

Sharma P, Kirmani MN (2015). Exploring depression \& anxiety among college going students. Int J Sci Res. 4(6): 528-532. https://www.ijsr.net/get_abstract.php?paper_id=SUB155259.
Sherina, Kaneson N (2003). The prevalence of depression among medical students. Malaysian J Psychiatry. 11(1): 12-17. https://citeseerx.ist.psu.edu/viewdoc/download?doi=10.1.1.498.99 65\&rep $=$ rep1\&type $=$ pdf.

Siregar AOA, Kustanti ER (2018). Hubungan antara gegar budaya dengan penyesuaian diri pada mahasiswa bersuku Minang di Universitas Diponegoro. Jurnal Empati. 7(2): 474-490.

Suryandari N (2012). Culture shock communication mahasiswa perantauan di Madura. Retrieved from http://www.jurnalkommas.com/docs/CULTURE \%20SHOCK\%2omahasiswa\%2operan tauan\%20di\%2omadura\%20_Jurnal \%20UNS_.pdf.

Thomson G, Rosenthal D (2006). Cultural stress among international students at an Australian University. Australian International Education Conference 2006.

WHO (2017). Depression and other common mental disorders. Global health estimates. Retrieved from https://apps.who.int/iris/bitstream/handle/1 0665/254610/WHO-MSD-MER-2017.2-eng.pdf.

Yu B (2010). Learning Chinese abroad: the role of language attitudes and motivation in the adaptation of international students in China. Journal of Multilingual and Multicultural Development. 31(3): 302-321. doi: 10.1080/01434631003735483.

Yuliza E (2015). Depresi dan penanganannya pada mahasiswa. Al-Ishlah Jurnal Pendidikan. 7(2): 179-195. doi: https://doi.org/10.35445/alishlah.v7i2.37. 